Acta Veterinaria Hungarica 62 (3), pp. 372-385 (2014)

DOI: $10.1556 /$ AVet 2014.012

First published online 19 July 2014

\title{
IN VITRO EFFECTS OF DOXORUBICIN AND DERACOXIB ON OXIDATIVE-STRESS-RELATED PARAMETERS IN CANINE MAMMARY CARCINOMA CELLS
}

\author{
Fulya ÜstÜN ALKAN ${ }^{1 *}$, Tülay BAKIREL ${ }^{1}$, Oya ÜSTÜNER ${ }^{1}$ and Hasret YARDIBI $^{2}$ \\ ${ }^{1}$ Department of Pharmacology and Toxicology, Faculty of Veterinary Medicine, \\ Istanbul University, Avcilar 34320, Istanbul, Turkey; ${ }^{2}$ Department of Biochemistry, \\ Faculty of Veterinary Medicine, Istanbul University, Istanbul, Turkey
}

(Received 3 September 2013; accepted 12 March 2014)

The present study evaluated the effects of doxorubicin (DOX) and deracoxib (DER), as single agents and in combination treatments, on antioxidant parameters in the canine mammary carcinoma cell line CMT-U27. The cells were exposed to DOX and DER for 24,48 and $72 \mathrm{~h}$. The viability and malondialdehyde (MDA), nitric oxide (NO), catalase (CAT), superoxide dismutase (SOD), glutathione peroxidase (GSHPx) and total glutathione (GSH) activities of CMT-U27 cells were determined. The half inhibition concentration $\left(\mathrm{IC}_{50}\right)$ of DOX was found to be $\sim 0.9 \mu \mathrm{M}$ in the 72 -h period. $\mathrm{IC}_{50}$ and $1 / 10 \mathrm{IC}_{50}$ concentrations of DOX were combined with all concentrations of DER $(50-1000 \mu \mathrm{M})$ in the combination experiments. The results showed increased oxidative status associated with significant decreases of CAT and GSH levels in CMT-U27 cells exposed to 10- $\mu \mathrm{M}$ and higher concentrations of DOX compared to control cells. In contrast, there were no significant changes in the groups tested with any of the concentrations of DER (50-1000 $\mu \mathrm{M})$. In combination treatments, DER attenuated DOX-induced oxidative damage by modulating the enzymatic and non-enzymatic components in CMT-U27 cells. We suggest that the combination of DOX and DER can be beneficial in the treatment of cancer cells by increasing cellular responses to oxidative stress. In conclusion, the use of COX inhibitor in conjunction with a chemotherapeutic agent may provide a basis for new concepts of cancer treatment through systematic modulation of the antioxidant defence systems in mammary cancers of animals.

Key words: Doxorubicin, deracoxib, oxidative stress, canine mammary cancer

Canine mammary tumours are the most common type of tumours, comprising about $50 \%$ of all neoplasms in female dogs (Karayannopoulou et al., 2001). The modalities used in the treatment of canine mammary cancer include

*Corresponding author; E-mail: fustun@istanbul.edu.tr; Phone: 0090 (212) 473-7070; Fax: 0090 (212) 473-7241 
surgery, radiotherapy or chemotherapy (Sorenmo, 2003). Chemotherapeutic regimes have been attempted in dogs with gross metastatic disease. Among the chemotherapeutic agents, anthracyclines such as doxorubicin (DOX) have been frequently used for their potent efficiency in controlling the distant spread of the disease (Pagnini et al., 2000). However, DOX continues to pose serious concern for the hazard of undesirable tissue consequences, such as generation of reactive oxygen species (ROS) resulting in oxidative stress and cellular changes. Overproduction of ROS can cause oxidative damage to biomolecules (lipids, proteins, DNA) and induce mitochondrial dysfunction and cell death, eventually leading to many chronic diseases including cardiovascular diseases, neural disorders, atherosclerosis, chronic inflammation, diabetes, cancer and other degenerative diseases (Uttara et al., 2009).

A disturbance of the balance between the formation of active oxygen metabolites and the rate at which they are scavenged by enzymatic and nonenzymatic antioxidants is referred to as oxidative stress (Papas, 1996). The extent of ROS-induced oxidative damage can be exacerbated by a decreased efficiency of antioxidant defence mechanisms. Endogenous defences against ROS include antioxidant enzymes such as catalase (CAT), superoxide dismutase (SOD) and glutathione peroxidase (GSHPx), and the markers of oxidative and nitrosative stress are malondialdehyde (MDA) and nitric oxide (NO) (Ray et al., 2000).

Oxidative stress is also a characteristic feature of inflammation, with epidemiological studies suggesting its positive association with cancer incidence in humans and animals with various types of cancer. In recent years, in vitro studies and clinical trials have shown that nonsteroidal anti-inflammatory drugs (NSAIDs) can modulate oxidative stress and contribute to decreasing the risk of several cancers (Antunes et al., 2007). Cyclooxygenase (COX) enzyme inhibition, which constitutes the primary mechanism of the anti-inflammatory action of NSAIDs, is believed to account for the suppression of cancer cell proliferation and tumor development. ROS are produced during the inflammatory response as a consequence of COX activity. However, it has been suggested that the antiinflammatory activity of NSAIDs may be also partly due to their ability to scavenge ROS (Fernandes et al., 2004). Since anti-inflammatory drugs can reduce oxygen radical species, such as superoxide anion, hydroxyl radical and hydrogen peroxide produced by inflammatory cells, they have been suggested to be effective antioxidant and protective agents (Antunes et al., 2007).

Recently, numerous experimental, epidemiological and clinical studies have demonstrated that NSAIDs, particularly the highly selective COX-2 inhibitors, are promising cancer chemopreventive agents (Rao and Reddy, 2004). Deracoxib (4-[5-(3-difluoro-4-methoxyphenyl)-(difluoromethyl)-1H pyrazole-1-yl] benzenesulphonamide) (DER) is a selective COX-2 inhibitor licensed for the treatment of pain and inflammation associated with osteoarthritis and orthopaedic surgery in canines (Cox et al., 2005). DER has been reported to possess po- 
tent antioxidant activity besides its anti-inflammatory effect (Yanez et al., 2008). On the basis of the concerns, we investigated the efficiency of the administration of DER with regard to its antioxidant ability in comparison to DOX as single agents and in combination treatments, on proliferation in conjunction with the levels of antioxidant parameters in CMT-U27 canine mammary carcinoma cell line.

\section{Materials and methods}

Chemicals

Except otherwise indicated, all reagents were purchased from Sigma Chemical Co. (St. Louis, MO, USA). MTT Cell Proliferation kit and Superoxide dismutase assay kit were purchased from Roche Applied Science (Mannheim, Germany) and Randox Laboratories Ltd. (UK), respectively. DER was a generous gift from Novartis Pharmaceuticals Inc. (Basle, Switzerland).

\section{Cell culture and treatment}

The canine mammary carcinoma cell line CMT-U27 was kindly supplied by Prof. Eva Héllmen (Uppsala University, Sweden). Cells were cultured in DMEM-F12 supplemented with $10 \%$ fetal bovine serum, $1 \% \mathrm{~L}$-glutamine and $1 \%$ antibiotic and antimycotic solution in a humidified atmosphere at $37{ }^{\circ} \mathrm{C}$ under $5 \% \mathrm{CO}_{2}$ and $95 \%$ air. Culture media were changed every $2-3$ days to maintain the exponential growth of the cells. DOX and DER were dissolved in DMEMF12 and sterile DMSO, respectively, and further serial dilutions for both drugs were made with DMEM-F12. All of the stock solutions were kept at $-20^{\circ} \mathrm{C}$.

\section{Cell viability assay}

The cells were seeded at $1 \times 10^{4}$ per well in a final volume of $100 \mu \mathrm{L}$ in 96-well flat-bottomed tissue culture plates and incubated in a humidified atmosphere at $37{ }^{\circ} \mathrm{C}$ under $5 \% \mathrm{CO}_{2}$ and $95 \%$ air to allow cell adhesion. After incubation, the medium was removed and cells were treated with various concentrations of $\operatorname{DOX}(0.1,1,10,50$ and $100 \mu \mathrm{M})$ and DER $(50,100,250,500$ and $1000 \mu \mathrm{M})$ for 24,48 and $72 \mathrm{~h}$. The concentrations for DOX were chosen on the basis of previous reports about the effects of this drug on the in vitro viability of canine mammary tumour cells (Pagnini et al., 2000). The tested DER levels were selected according to the values reported in an earlier study (Royals et al., 2005) to cause inhibition of proliferation of a canine osteosarcoma cell line. Cell viability, based on mitochondrial dehydrogenase activity, was determined using the colorimetric assay MTT (3-(4,5)-dimethylthiazol-2-yl)-2,5-diphenyltetrazolium bromide) Cell Proliferation Kit in accordance with the instruction manual. The optical density of each well at $550 \mathrm{~nm}$ against a reference wavelength of $650 \mathrm{~nm}$ was measured 
using a microplate reader (ELx800, Biotek Instruments, USA). The cell viability was calculated as follows: Viability $(\%)=($ Absorbance of the treated wells $) /$ (Absorbance of the control wells) $\times 100$. Each concentration was tested in three different experiments and run in triplicate. The dose-response curves were plotted for each drug and the concentration of drug required for $50 \%$ inhibition of cell viability $\left(\mathrm{IC}_{50}\right)$ was determined graphically. In drug combination experiments, the $\mathrm{IC}_{50}$ and $1 / 10 \mathrm{IC}_{50}$ concentrations of DOX were used in combination with all concentrations of DER for $72 \mathrm{~h}$.

Determination of oxidative stress markers and enzymatic and non-enzymatic antioxidants

Enzymatic (CAT, SOD, GSHPx) and non-enzymatic antioxidants (GSH) were determined in cell lysates prepared according to the method described by Jung et al. (1997). Briefly, cell pellets were suspended in 0.1\% Triton X-100 solution in $10 \mathrm{mM}$ phosphate buffer $(\mathrm{pH}$ 7.2) and sonicated. After centrifugation $(13,000 \times \mathrm{g} ; 10 \mathrm{~min})$, the supernatants of cell lysates were collected and stored until analysis of MDA, CAT, SOD, GSHPx and GSH at $-80^{\circ} \mathrm{C}$. The protein content of the cell lysates was measured using the Total Protein Kit for lipid peroxidation, catalase and superoxide dismutase assays (Sigma, St. Louis, MO). Each experiment was carried out in triplicate.

\section{Lipid peroxidation assay}

Lipid peroxidation products were quantified by measuring thiobarbituric acid reactive substances and expressed as MDA (Draper and Hadley, 1990). The cells were seeded at $2.5 \times 10^{5}$ per well in a final volume of $1000 \mu \mathrm{L}$ in 24 -well flat-bottomed tissue culture plates and incubated in a humidified atmosphere at $37{ }^{\circ} \mathrm{C}$ under $5 \% \mathrm{CO}_{2}$ and $95 \%$ air to allow cell adhesion. Subsequently, the medium was removed and fresh medium containing various concentrations of drugs as mentioned in the MTT test were added and incubated at $37^{\circ} \mathrm{C}$ in a $5 \% \mathrm{CO}_{2}$ atmosphere incubator for $72 \mathrm{~h}$. After the incubation period, the experiment was performed according to the method described by Kim et al. (2007). The results were expressed as MDA formation per mg protein.

\section{Nitric oxide (NO) assay}

The cells were seeded at $1 \times 10^{5}$ per well in a final volume of $1000 \mu \mathrm{L}$ in 24-well flat-bottomed tissue culture plates and incubated as mentioned under the lipid peroxidation assay. At the end of the incubation period the supernatants were collected. The concentration of nitrites $\left(\mathrm{NO}_{2}\right)$ in supernatants of cells was taken as a measure of NO production and determined via the Griess reaction. Optical density was determined at $530 \mathrm{~nm}$ with a microplate reader and $\mathrm{NO}_{2}$ levels were measured by comparison to the sodium nitrite $\left(\mathrm{NaNO}_{2}\right)$ standard curve (Chen et al., 2008). 


\section{Catalase (CAT) assay}

CAT activity was determined by the spectrophotometric method by measuring the decomposition of $\mathrm{H}_{2} \mathrm{O}_{2}$ at $240 \mathrm{~nm}$ using an extinction coefficient of $43.6 \mathrm{M}^{-1} \mathrm{~cm}^{-1}$ and an initial $\mathrm{H}_{2} \mathrm{O}_{2}$ concentration of $54 \mathrm{mM}$. One unit of CAT activity is defined as the amount of enzyme catalysing the breakdown of $1 \mu \mathrm{mol}$ of $\mathrm{H}_{2} \mathrm{O}_{2}$ per min at $25^{\circ} \mathrm{C}$ (Beer and Sizer, 1952). Each unit was expressed as activity per $\mathrm{mg}$ protein.

\section{Superoxide dismutase (SOD) assay}

The SOD activity assay was based on the ability of the enzyme to convert superoxide radicals, produced by $\mathrm{X} / \mathrm{XO}$, to hydrogen peroxide, inhibiting indicator oxidation and colour formation. The possible influence of drugs on the SOD activity were determined with a RANSOD test kit (Randox Laboratories Ltd., UK) as described by Rengel et al. (2005). Each unit was expressed as activity per mg protein.

\section{Glutathione peroxidase (GSHPx) assay}

GSHPx activity was determined with a spectrophotometer by measuring the rate of NADPH oxidation at $340 \mathrm{~nm}$ (Koh, 2001). The decrease in $A_{340}$ was recorded for 6 min at 1-min intervals. Enzyme activity was calculated by using the millimolar extinction coefficient of NADPH (6.22). One milliunit of GSHPx oxidises $1 \mathrm{nmol}$ of GSH per min.

\section{Glutathione (GSH) assay}

Samples were examined for the level of GSH by Tietze's method described by Durgo et al. (2007). The absorbance was determined at $412 \mathrm{~nm}$ every $15 \mathrm{sec}$ for $2 \mathrm{~min}$. The concentration of total GSH was calculated from the standard curve.

\section{Statistical analysis}

Data were analysed by one-way analysis of variance (ANOVA) followed by Student's $t$-test using the 'Instat' statistical computer programme. Results were expressed as the mean $\pm \mathrm{SE}$. Differences were considered statistically significant at a $\mathrm{P}$ value of 0.05 or less.

\section{Results}

Cell viability assay

DOX and DER displayed dose- and time-dependent antiproliferative effects in CMT-U27 cells (data not shown). After 72-h incubation, a significant reduction in cell numbers was seen in the presence of all concentrations of DOX 
$(\mathrm{P}<0.001)$ and $250 \mu \mathrm{M}, 500 \mu \mathrm{M}(\mathrm{P}<0.05)$ and $1000 \mu \mathrm{M}$ of DER $(\mathrm{P}<0.01)$ (Fig. 1). The $\mathrm{IC}_{50}$ value was calculated for DOX and DER at concentrations of $0.876 \mu \mathrm{M}$ and $974.481 \mu \mathrm{M}$, respectively, after 72-h incubation. Accordingly, the $\mathrm{IC}_{50}$ and $1 / 10 \mathrm{IC}_{50}$ values of DOX were used in the subsequent studies on oxidative stress. The combinations of $\mathrm{IC}_{50}$ and $1 / 10 \mathrm{IC}_{50}$ values of DOX with the highest dose of DER resulted in significant reductions of cell viability $(\mathrm{P}<0.05, \mathrm{P}<$ 0.01 ), respectively (Fig. 2).

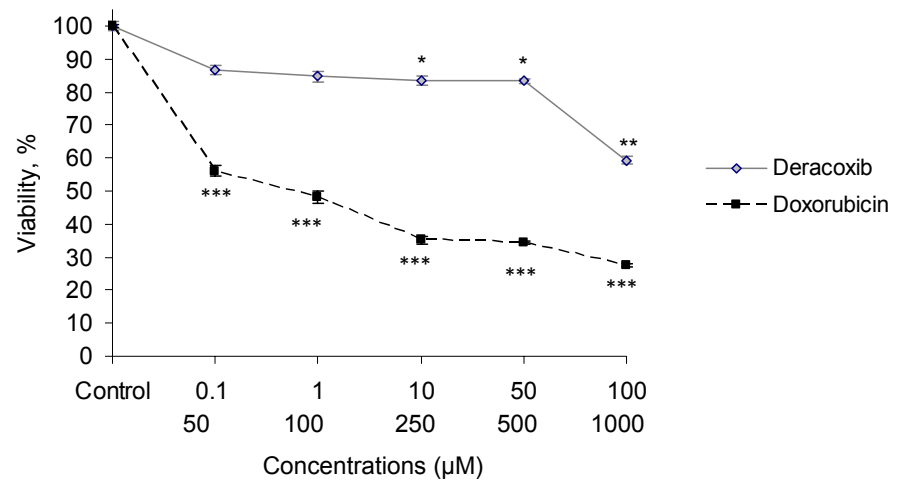

Fig. 1. CMT-U27 cell viability after 72-h exposure to DOX and DER. Values are mean \pm SE from three independent experiments. Significant differences indicated as ${ }^{* * *} \mathrm{P}<0.001$ DOX vs. control group, ${ }^{*} \mathrm{P}<0.05$ and ${ }^{* *} \mathrm{P}<0.01$ DER vs. control group

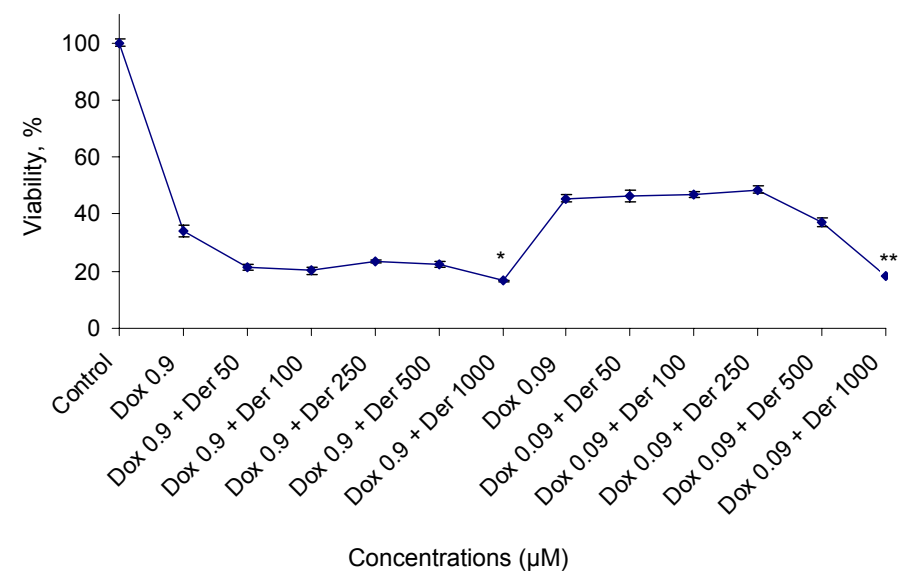

Fig. 2. CMT-U27 cell viability after 72-h exposure to DOX and DER combination. Values are mean \pm SE from three independent experiments. Significant differences indicated as ${ }^{*} \mathrm{P}<0.05$ DOX combinations vs. DOX $(0.9 \mu \mathrm{M}),{ }^{* *} \mathrm{P}<0.01$ DOX combinations vs. DOX $(0.09 \mu \mathrm{M})$ 


\begin{tabular}{|c|c|c|c|c|c|c|}
\hline \multirow{3}{*}{$\begin{array}{l}\text { Concentrations } \\
\text { of drugs }^{\mathrm{b}}\end{array}$} & \multicolumn{6}{|c|}{ IDA, $\mathrm{NO}_{2}, \mathrm{CAT}, \mathrm{SOD}, \mathrm{GSHPx}$ and GSH levels of CMT-U27 ce } \\
\hline & \multicolumn{6}{|c|}{ Parameters $^{\mathrm{a}}$} \\
\hline & $\begin{array}{c}\mathrm{MDA}, \\
\mathrm{nmol} / \mathrm{mg} \text { protein }\end{array}$ & $\begin{array}{l}\mathrm{NO}_{2}, \\
\mu \mathrm{M}\end{array}$ & $\begin{array}{c}\text { CAT, } \\
\mathrm{U} / \mathrm{mg} \text { protein }\end{array}$ & $\begin{array}{c}\text { SOD, } \\
\mathrm{U} / \mathrm{mg} \text { protein }\end{array}$ & $\begin{array}{l}\text { GSHPx, } \\
\mathrm{nmol} / \mathrm{mL}\end{array}$ & $\underset{\mu \mathrm{M}}{\mathrm{GSH}}$ \\
\hline Control & $5.63 \pm 0.24$ & $3.45 \pm 0.82$ & $1.76 \pm 0.05$ & $0.30 \pm 0.02$ & $463.52 \pm 17.39$ & $1.48 \pm 0.04$ \\
\hline DOX $0.1 \mu \mathrm{M}$ & $8.68 \pm 1.04$ & $3.71 \pm 1.01$ & $1.23 \pm 0.70$ & $0.29 \pm 0.01$ & $371.89 \pm 20.59$ & $1.41 \pm 0.03$ \\
\hline $\mathrm{DOX} 1 \mu \mathrm{M}$ & $9.60 \pm 0.23$ & $4.64 \pm 0.95$ & $1.12 \pm 0.58$ & $0.26 \pm 0.01$ & $355.44 \pm 17.13$ & $1.16 \pm 0.04$ \\
\hline DOX $10 \mu \mathrm{M}$ & $9.46 \pm 0.39$ & $4.17 \pm 0.18$ & $0.93 \pm 0.49^{*}$ & $0.23 \pm 0.02$ & $330.52 \pm 10.85$ & $0.95 \pm 0.04^{*}$ \\
\hline DOX $50 \mu \mathrm{M}$ & $10.15 \pm 1.95$ & $6.25 \pm 0.23$ & $0.91 \pm 0.04^{*}$ & $0.20 \pm 0.01$ & $327.64 \pm 9.10$ & $0.93 \pm 0.02^{*}$ \\
\hline DOX $100 \mu \mathrm{M}$ & $21.34 \pm 0.48^{*}$ & $14.89 \pm 0.17^{*}$ & $0.88 \pm 0.07^{*}$ & $0.12 \pm 0.01^{*}$ & $278.51 \pm 14.34^{*}$ & $0.88 \pm 0.04^{*}$ \\
\hline DER $50 \mu \mathrm{M}$ & $3.76 \pm 0.80$ & $4.18 \pm 0.14$ & $1.84 \pm 0.05$ & $0.27 \pm 0.01$ & $407.38 \pm 11.58$ & $1.19 \pm 0.06$ \\
\hline DER $100 \mu \mathrm{M}$ & $3.70 \pm 0.29$ & $4.05 \pm 0.18$ & $2.07 \pm 0.07$ & $0.28 \pm 0.01$ & $444.33 \pm 9.88$ & $1.31 \pm 0.05$ \\
\hline DER $250 \mu \mathrm{M}$ & $4.49 \pm 0.63$ & $2.02 \pm 0.20$ & $2.57 \pm 0.08$ & $0.30 \pm 0.01$ & $472.41 \pm 13.86$ & $1.39 \pm 0.04$ \\
\hline DER $500 \mu \mathrm{M}$ & $7.46 \pm 0.07$ & $1.87 \pm 0.19$ & $2.65 \pm 0.08$ & $0.34 \pm 0.02$ & $592.44 \pm 15.27$ & $1.84 \pm 0.04$ \\
\hline DER $1000 \mu \mathrm{M}$ & $7.21 \pm 0.70$ & $2.63 \pm 0.41$ & $2.73 \pm 0.06$ & $0.43 \pm 0.02$ & $625.42 \pm 12.38$ & $1.95 \pm 0.06$ \\
\hline
\end{tabular}

${ }^{\mathrm{a}} \mathrm{MDA}$, malondialdehyde; $\mathrm{NO}_{2}$, nitrite; CAT, catalase; SOD, superoxide dismutase; GSHPx, glutathione peroxidase; GSH, glutathione; ${ }^{\mathrm{b}} \mathrm{DOX}$, Doxorubicin; DER, Deracoxib. Each value represents the mean $\pm \mathrm{SE}$ of three experiments; ${ }^{*} \mathrm{P}<0.05$ compared to the control group 
Table 2

MDA, $\mathrm{NO}_{2}$, CAT, SOD, GSHPx and GSH levels of CMT-U27 cells after 72-h exposure to DOX and DER combination

\begin{tabular}{|c|c|c|c|c|c|c|}
\hline \multirow{2}{*}{$\begin{array}{l}\text { Concentrations } \\
\text { of drugs }{ }^{b}(\mu \mathrm{M})\end{array}$} & \multicolumn{6}{|c|}{ Parameters $^{\mathrm{a}}$} \\
\hline & $\begin{array}{c}\text { MDA, } \\
\mathrm{nmol} / \mathrm{mg} \text { protein }\end{array}$ & $\begin{array}{l}\mathrm{NO}_{2} \\
\mu \mathrm{M}\end{array}$ & $\begin{array}{c}\text { CAT, } \\
\mathrm{U} / \mathrm{mg} \text { protein }\end{array}$ & $\begin{array}{c}\text { SOD, } \\
\text { U/mg protein }\end{array}$ & $\begin{array}{l}\text { GSHPx, } \\
\mathrm{nmol} / \mathrm{mL}\end{array}$ & $\begin{array}{l}\mathrm{GSH}, \\
\mu \mathrm{M}\end{array}$ \\
\hline Control & $5.63 \pm 0.24$ & $3.45 \pm 0.82$ & $1.76 \pm 0.05$ & $0.30 \pm 0.02$ & $463.52 \pm 17.39$ & $1.48 \pm 0.04$ \\
\hline DOX 0.9 & $8.85 \pm 0.39$ & $4.53 \pm 0.35$ & $1.34 \pm 0.03$ & $0.27 \pm 0.02$ & $364.34 \pm 10.07$ & $1.22 \pm 0.03$ \\
\hline DOX $0.9+$ DER 50 & $5.43 \pm 0.33$ & $4.00 \pm 0.06$ & $1.23 \pm 0.05$ & $0.26 \pm 0.01$ & $330.46 \pm 7.38$ & $1.11 \pm 0.12$ \\
\hline DOX $0.9+$ DER 100 & $7.47 \pm 0.99$ & $2.77 \pm 0.67$ & $1.71 \pm 0.06$ & $0.28 \pm 0.03$ & $441.86 \pm 8.94$ & $1.33 \pm 0.03$ \\
\hline DOX $0.9+$ DER 250 & $7.72 \pm 0.16$ & $1.04 \pm 0.14$ & $1.80 \pm 0.05$ & $0.33 \pm 0.02$ & $460.17 \pm 15.61$ & $1.26 \pm 0.02$ \\
\hline DOX 0.9 + DER 500 & $8.01 \pm 0.36$ & $1.76 \pm 0.20$ & $1.98 \pm 0.07$ & $0.34 \pm 0.04$ & $540.67 \pm 18.07$ & $1.68 \pm 0.04$ \\
\hline DOX $0.9+$ DER 1000 & $8.67 \pm 0.44$ & $1.01 \pm 0.23$ & $2.53 \pm 0.08^{*}$ & $0.36 \pm 0.04$ & $606.18 \pm 12.14^{*}$ & $2.07 \pm 0.01^{*}$ \\
\hline DOX 0.09 & $7.47 \pm 0.13$ & $3.63 \pm 0.34$ & $1.41 \pm 0.02$ & $0.29 \pm 0.01$ & $376.91 \pm 9.39$ & $1.39 \pm 0.04$ \\
\hline DOX $0.09+$ DER 50 & $6.61 \pm 0.71$ & $3.09 \pm 0.124$ & $1.66 \pm 0.05$ & $0.30 \pm 0.01$ & $341.95 \pm 14.27$ & $1.20 \pm 0.01$ \\
\hline DOX $0.09+$ DER 100 & $6.66 \pm 0.37$ & $2.37 \pm 0.29$ & $1.77 \pm 0.08$ & $0.34 \pm 0.03$ & $387.09 \pm 11.76$ & $1.50 \pm 0.02$ \\
\hline DOX $0.09+$ DER 250 & $5.99 \pm 0.58$ & $2.06 \pm 0.03$ & $1.91 \pm 0.07$ & $0.34 \pm 0.04$ & $538.39 \pm 16.67$ & $1.52 \pm 0.03$ \\
\hline DOX $0.09+$ DER 500 & $6.44 \pm 0.36$ & $1.99 \pm 0.08$ & $2.26 \pm 0.06$ & $0.37 \pm 0.04$ & $799.76 \pm 21.84^{* *}$ & $2.03 \pm 0.08$ \\
\hline DOX 0.09 + DER 1000 & $6.62 \pm 0.29$ & $2.28 \pm 0.32$ & $2.62 \pm 0.05^{*}$ & $0.41 \pm 0.06$ & $781.93 \pm 26.47^{* *}$ & $2.15 \pm 0.06^{*}$ \\
\hline
\end{tabular}

${ }^{a} \mathrm{MDA}$, malondialdehyde; $\mathrm{NO}_{2}$, nitrite; CAT, catalase; SOD, superoxide dismutase; GSHPx, glutathione peroxidase; GSH, glutathione; ${ }^{\mathrm{b}} \mathrm{DOX}$, Doxorubicin; DER, Deracoxib. Each value represents the mean \pm SE of three experiments; ${ }^{*} \mathrm{P}<0.05$ compared to DOX $(0.9 \mu \mathrm{M}$ and $0.09 \mu \mathrm{M})$; ${ }^{* *} \mathrm{P}<0.01$ compared to DOX $(0.9 \mu \mathrm{M}$ and $0.09 \mu \mathrm{M})$ 
Determination of oxidative stress markers and enzymatic and non-enzymatic antioxidants

The effects of DOX and DER on MDA, $\mathrm{NO}_{2}, \mathrm{CAT}$, SOD, GSHPx and GSH levels in CMT-U27 cells are shown in Table 1. The effects of the combination of DOX and DER on MDA, $\mathrm{NO}_{2}, \mathrm{CAT}$, SOD, GSHPx and GSH levels in CMT-U27 cells are shown in Table 2.

\section{Lipid peroxidation assay}

The highest dose of DOX $(100 \mu \mathrm{M})$ markedly increased MDA levels $(\mathrm{P}<$ $0.05)$, whereas DER had no significant effect on lipid peroxidation. However, DER in combination with DOX suppressed lipid peroxidation but this suppression was not statistically significant $(\mathrm{P}>0.05)$.

\section{Nitric oxide assay}

As the data show, DOX increased the $\mathrm{NO}_{2}$ release when compared with the control. A significant increase $(\mathrm{P}<0.05)$ was seen at the highest dose $(100 \mu \mathrm{M})$, whereas none of the doses of DER had significant effects on $\mathrm{NO}_{2}$ levels when compared with the control. A small and statistically insignificant $(\mathrm{P}>0.05)$ effect on $\mathrm{NO}_{2}$ levels was observed for DOX combinations with all doses of DER when compared with DOX $(0.9$ and $0.09 \mu \mathrm{M})$.

\section{Catalase (CAT) assay}

CAT levels were decreased in a dose-dependent manner and a significant reduction $(\mathrm{P}<0.05)$ was seen at $10 \mu \mathrm{M}$ and higher concentrations of DOX. However, DER had no significant effect on CAT levels. In contrast, significant rises $(\mathrm{P}<0.05)$ in CAT levels were detected after treatment with $0.9 \mu \mathrm{M}$ and $0.09 \mu \mathrm{M}$ concentrations of DOX combined with the highest dose $(1000 \mu \mathrm{M})$ of DER.

Superoxide dismutase (SOD) assay

The SOD levels were significantly decreased $(\mathrm{P}<0.05)$ in the presence of DOX $(100 \mu \mathrm{M})$, whereas the relatively small increases in SOD levels seen after treatment with DER $(250-1000 \mu \mathrm{M})$ in comparison with the control were not statistically significant $(\mathrm{P}>0.05)$. The combination of DOX with DER had no significant effect on SOD levels when compared with DOX $(0.9$ and $0.09 \mu \mathrm{M})$.

\section{Glutathione peroxidase (GSHPx) assay}

DOX $(100 \mu \mathrm{M})$ significantly decreased GSHPx activity in comparison with the control group $(\mathrm{P}<0.05)$, while the small increases induced in the activity of GSHPx by $250 \mu \mathrm{M}$ and higher concentrations of DER did not carry statistical significance. Combined treatment with DOX and DER $(0.9 \mu \mathrm{M}$ DOX + 
$1000 \mu \mathrm{M}$ DER, $0.09 \mu \mathrm{M}$ DOX $+500 \mu \mathrm{M}$ DER and $0.09 \mu \mathrm{M}$ DOX $+1000 \mu \mathrm{M}$ DER) significantly increased the GSHPx level compared to DOX alone at 0.9 and $0.09 \mu \mathrm{M}$ $(\mathrm{P}<0.05, \mathrm{P}<0.01)$.

\section{Glutathione (GSH) assay}

DOX decreased the GSH levels significantly at $10 \mu \mathrm{M}$ and higher doses $(\mathrm{P}<0.05)$ and there was a tendency for an increase in GSH concentrations at 500 and $1000 \mu \mathrm{M}$ concentrations of DER. However, DOX treatment combined with $1000 \mu \mathrm{M}$ of DER caused a more than 1.55- to 1.70-fold increase in GSH levels in CMT-U27 cells when compared with DOX used alone at 0.9 and $0.09 \mu \mathrm{M}$.

\section{Discussion}

Cellular mechanisms and external factors involved in the production of oxidative stress include the inflammatory response, free radical leak from mitochondria, auto-oxidation of catecholamines, xanthine oxidase activation and prooxidant activities of toxins. Aerobic cells are endowed with extensive antioxidant defence mechanisms including low molecular weight scavengers and enzymatic systems such as SOD, CAT, GSHPx and GSH, which counteract the damaging effects of ROS (Russo et al., 2005).

DOX is a potent chemotherapeutic agent, used for the treatment of canine mammary cancer (Sorenmo, 2003). Application of this drug can cause serious side effects in various tissues including kidney and brain (nephrotoxicity and neurotoxicity), apart from the known serious cardiotoxic side effects which are caused by the free radical formation activity of DOX (Joshi et al., 2005). These side effects limit the successful use of this drug in the treatment of cancer (Kotamraju et al., 2000). The cellular and biochemical changes involved in the DOX-induced injury of membrane lipids have been demonstrated (Shiromwar and Chidrawar, 2011). Modulations of the oxidant status by systemic alteration of the enzymatic antioxidant systems and of the nonenzymatic components as well as by inducing an increased release of radicals have recently been under discussion as concepts of cancer treatment. We consider the data obtained in the present study as a basis for further investigations in this field.

Lipid peroxidation initiated by ROS is a complex process that occurs in multiple stages, and measurements of MDA levels as well as GSH content and antioxidant enzyme activities have been used as markers for oxidative stress in cultures in vitro (Alía et al., 2006). The most important mechanism for free radical scavenging and inhibition of electrophilic xenobiotics attack on cellular macromolecules involves tripeptide GSH (Durgo et al., 2007). GSH is one of the most abundant thiol-containing molecules in animal cells, which plays an important role in the protection of tissues from the toxic effects of xenobiotics and endoge- 
nous electrophiles. Reactive intermediates can react with GSH either by a direct chemical reaction or by a glutathione-S-transferase mediated reaction preventing possible cell death (Forman et al., 2009). In the present study, there was a decrease in GSH concentration in DOX-treated cells compared with the control group. This decrease may be caused by GSH reacting with increased free radicals or lipid peroxides. However, the combination of $1000 \mu \mathrm{M}$ of DER with the $\mathrm{IC}_{50}$ and $1 / 10 \mathrm{IC}_{50}$ values of DOX significantly increased the GSH levels in CMT-U27 cells as compared with the $\mathrm{IC}_{50}$ and $1 / 10 \mathrm{IC}_{50}$ values of $\mathrm{DOX}$ alone. This indicates that cells treated with DER can tolerate exposure to higher concentrations of DOX as well as antineoplastic drugs that cause oxidative damage and oxidative stress.

CAT is a primary antioxidant defence that converts $\mathrm{H}_{2} \mathrm{O}_{2}$ to $\mathrm{O}_{2}$ and water, and SOD is thought to provide a primary line of defence by catalysing the dismutation of the one-electron reduction product of oxygen $\mathrm{O}_{2}$ to $\mathrm{H}_{2} \mathrm{O}_{2}$ and $\mathrm{O}_{2}$, and SOD has a central role in the protection of cancer cells against intrinsic oxidative stress (Oberley and Buettner, 1979; Valko et al., 2006). Decreased CAT activity in tumour cells leads to the accumulation of $\mathrm{H}_{2} \mathrm{O}_{2}$, which causes DNA damage and/or cell death (Er et al., 2004). Also, $\mathrm{H}_{2} \mathrm{O}_{2}$ is believed to be involved in the initiation and promotion of carcinogenesis (Pryor, 1986). The significant decrease in CAT levels might be a result of excess production of $\mathrm{H}_{2} \mathrm{O}_{2}$ and consequently free radicals. CAT might act as a compensatory mechanism to overcome the excess of $\mathrm{H}_{2} \mathrm{O}_{2}$. The increase in CAT levels seen after combined treatment may be due to the antioxidant activity of DER. The lowered values of CAT, SOD and GSH found in this study strongly prove the oxidative damage caused by DOX. In addition, it was observed that DER was capable of restoring CAT, SOD and GSH that had been reduced by DOX. However, significant increases in CAT and GSH levels were found only at the highest concentration of DER. The reduction of oxidative stress by DER can be explained by the potential antioxidant capacity of DER. This argument is supported by the finding that DER had a steadily high antioxidant activity $(\sim 0.4 \mathrm{mM})$ when measured by the ABTS method (Yanez et al., 2008). The alterations caused in antioxidant enzyme activities by DER may be due to direct scavenging of the peroxyl radical or by donating reducing equivalents to the peroxyl radical (Ajith et al., 2005).

In the present study, DOX significantly reduced cell viability in a timedependent manner. DER had only minimal effect on DOX-induced cytotoxicity when combined with the $\mathrm{IC}_{50}$ and $1 / 10 \mathrm{IC}_{50}$ values of DOX. Only the highest tested concentration of DER $(1000 \mu \mathrm{M})$ enhanced the cytotoxic activities of DOX significantly. Previous studies have shown that DOX toxicity can be mediated by the redox-shift dependent pathway as well as by topoisomerase II inhibition; the latter leads to DNA cleavage, caspase-3 activation and eventually apoptosis (Mizutani et al., 2005). In our previous study, we have shown that DER induced apoptosis at $250 \mu \mathrm{M}$ and higher concentrations in CMT-U27 cells (Üstün Alkan et al., 2012). Thus, it appears that DER-induced apoptosis may have contributed 
to cell death. We suggested that DER-induced apoptosis of CMT-U27 cells was accompanied by alterations in antioxidant enzyme activities.

Although NSAIDs are long-established and commonly used medications, their use as combination partners of conventional chemotherapeutic agents is very new and many things remain to be clarified. Considering that chemotherapeutic agents increase oxidative stress and lower antioxidant capacity, NSAIDs may greatly improve therapeutic strategies. In the present study, we showed that DER attenuated DOX-induced oxidative damage by modulating oxidant status in CMT-U27 cells. We suggest that the combination of DOX and DER can be beneficial in the treatment of cancer cells by increasing cellular responses to oxidative stress. Although an antioxidant property of DER has only been observed at high concentrations $(500$ and $1000 \mu \mathrm{M})$, these doses can be toxic in dogs. Also, the clinical benefit of using a DOX and DER combination in canine mammary cancer patients is not known; therefore, in vivo clinical studies need to be conducted and evaluated to determine whether the combination of DOX and DER can be used safely in animals.

In conclusion, the use of a COX inhibitor in combination with a chemotherapeutic agent may provide a basis for new concepts of cancer treatment with the help of systematic modulations of the antioxidant defence systems in mammary cancer of animals.

\section{Acknowledgements}

This study was supported by TUBITAK (Project no.: 1080296) and the Research Fund of Istanbul University (Project no.: UDP-6854).

\section{References}

Ajith, T., Subin, J. P., Jacob, J., Sanjay, P. S. and Babitha, N. V. (2005): Antimutagenic and antioxidant activities of the non-steroidal anti-inflammatory drug celecoxib. Clin. Exp. Pharmacol. Physiol. 32, 888-893.

Alía, M., Ramos, S., Mateos, R., Granado-Serrano, A., Bravo, L. and Goya, L. (2006): Quercetin protects human hepatoma HepG2 against oxidative stress induced by tert-butyl hydroperoxide. Toxicol. Appl. Pharm. 212, 110-118.

Antunes, L. M., de Barros, E. L. B., da Luz Dias, F. and de Lourdes, P. B. M. (2007): Acetylsalicylic acid exhibits anticlastogenic effects on cultured human lymphocytes exposed to doxorubicin. Mutat. Res. 626, 155-161.

Beer, R. F. and Sizer, W. I. (1952): A spectrophotometric method for measuring the breakdown of $\mathrm{H}_{2} \mathrm{O}_{2}$ by catalase. J. Biol. Chem. 195, 133-140.

Chen, L., Yang, L. and Wang, C. (2008): Anti-inflammatory activity of mangostins from Garcinia mangostana. Food Chem. Toxicol. 46, 688-693.

Cox, S. K., Roark, J., Gassel, A. and Tobias, K. (2005): Determination of deracoxib in feline plasma samples using high performance liquid chromatography. J. Chromatogr. B 819, 181-184.

Draper, H. H. and Hadley, M. (1990): Malondialdehyde determination as index of lipid peroxidation. Method Enzymol. 186, 421-431. 
Durgo, K., Vuković, L., Rusak, G., Osmak, M. and Čolić, J. F. (2007): Effect of flavonoids on glutathione level, lipid peroxidation and cytochrome P450 CYP1A1 expression in human laryngeal carcinoma cell lines. Food Technol. Biotechnol. 45, 69-79.

Er, T., Hou, M., Tsa, E., Lee, J. and Tsai, L. (2004): Differential expression of manganese containing superoxide dismutase in patients with breast cancer in Taiwan. Ann. Clin. Lab. Sci. 34, $159-164$.

Fernandes, E., Costa, D., Toste, S. A., Lima, J. L. F. C. and Reis, S. (2004): In vitro scavenging activity for reactive oxygen and nitrogen species by nonsteroidal anti-inflammatory indole, pyrrole, and oxazole derivative drugs. Free Radical Bio. Med. 37, 1895-1905.

Forman, H. J., Zhang, H. and Rinna, A. (2009): Glutathione: Overview of its protective roles, measurement, and biosynthesis. Mol. Aspects Med. 30, 1-12.

Joshi, G., Sultana, R., Tangpong, J., Cole, M. P., Clair, D. K., Vore, M., Estus, S. and Butterfield, D. A. (2005): Free radical mediated oxidative stress and toxic side effects in brain induced by the anti cancer drug adriamycin: Insight into chemobrain. Free Radical Res. 39, 1147-1154.

Jung, K., Seidel, B., Rudolph, B., Lein, M., Cronauer, V. M., Henke, W., Hampel, G., Schnorr, D. and Loening, A. S. (1997): Antioxidant enzymes in malignant prostate cell lines and in primary cultured prostatic cells. Free Radical Bio. Med. 23, 127-133.

Karayannopoulou, M., Kaldrymidou, E., Constantinidis, T. C. and Dessiris, A. (2001): Adjuvant post-operative chemotherapy in bitches with mammary cancer. J. Vet. Med. A Physiol Pathol. Clin. Med. 48, 85-96.

Kim, K. T., Yoo, K. M., Lee, J. W., Eom, S. H., Hwang, I. K. and Lee, C. Y. (2007): Protective effect of steamed American ginseng (Panax quinquefolius L.) on V79-4 cells induced by oxidative stress. J. Ethnopharmacol. 111, 443-450.

Koh, Y. (2001): Alterations in the activities of antioxidant enzymes of human dermal microvascular endothelial cells infected with Orientia tsutsugamushi. J. Microbiol. 39, 142-145.

Kotamraju, S., Konorev, E. A., Joseph, J. and Kalyanaraman, B. (2000): Doxorubicin-induced apoptosis in endothelial cells and cardiomyocytes is ameliorated by nitrone spin traps and ebselen. Role of reactive oxygen and nitrogen species. J. Biol. Chem. 275, 33585-33592.

Mizutani, H., Tada-Oikawa, S., Hiraku, Y., Kojima, M. and Kawanishi, S. (2005): Mechanism of apoptosis induced by doxorubicin through the generation of hydrogen peroxide. Life Sci. 76, 1439-1453.

Oberley, L. W. and Buettner, G. R. (1979): Role of superoxide dismutase in cancer: A review. Cancer Res. 39, 1141-1149.

Pagnini, U., Florio, S., Lombardi, P., d'Angelo, D., Avallone, L., Galdiero, M., Iovane, G., Tortora, G. and Pagnini, G. (2000): Modulation of anthracycline activity in canine mammary tumour cells in vitro by medroxyprogesterone acetate. Res. Vet. Sci. 69, 255-262.

Papas, M. A. (1996): Determinants of antioxidant status in humans. Lipids 31, 77-82.

Pryor, W. A. (1986): Cancer and free radicals. In: Shankerl, D. M., Hartman, P., Kada, T. and Hollaender, A. (eds) Antimutagenesis and Anticarcinogenesis Mechanisms. Plenum Press, New York. pp. 45-59.

Rao, C. V. and Reddy, B. S. (2004): NSAIDS and chemoprevention. Curr. Cancer Drug Tar. 4, 29-42.

Ray, G., Batra, S., Shukla, N. K., Deo, S., Raina, V., Ashok, S. and Husain, S. A. (2000): Lipid peroxidation, free radical production and antioxidant status in breast cancer. Breast Cancer Res. Tr. 59, 163-170.

Rengel, G. R., Filipović-Grčic, Č. I., Žanić-Grubišić, T. and Barišić, K. (2005): The effect of liposomes with superoxide dismutase on A2182 cells. Eur. J. Pharm Biopharm. 60, 47-51.

Royals, S. R., Farese, J. P., Milner, R. J., Lee-Ambrose, L. and van Gilder, J. (2005): Investigation of the effects of deracoxib and piroxicam on the in vitro viability of osteosarcoma cells from dogs. Am. J. Vet. Res. 66, 1961-1967.

Russo, A., Cardile, V., Lombardo, L., Vanella, L., Vanella, A. and Garbario, J. A. (2005): Antioxidant activity and antiproliferative action of methanolic extract of Geum quellyon sweet roots in human tumor cell lines. J. Ethnopharmacol. 100, 323-332. 
Shiromwar, S. S. and Chidrawar, V. R. (2011): Combined effects of $p$-coumaric acid and naringenin against doxorubicin-induced cardiotoxicity in rats. Pharmacogn. Res. 3, 214-219.

Sorenmo, K. (2003): Canine mammary gland tumors. Vet. Clin. N. Am. 33, 573-596.

Uttara, B., Singh, A. V., Zamboni, P. and Mahajan, R. T. (2009): Oxidative stres and neurodegenerative diseases: A review of upstream and downstream antioxidant therapeutic options. Curr. Neuropharmacol. 7, 65-74.

Üstün Alkan, F., Üstüner, O., Bakırel, T., Cınar, S., Erten, G. and Deniz, G. (2012): The effects of piroxicam and deracoxib on canine mammary tumour cell line. The Sci. World J. 2012, Article ID 976740.

Valko, M., Rhodes, C. J., Moncol, J., Izakovica, M. and Mazur, M. (2006): Free radicals, metals and antioxidants in oxidative stress-induced cancer. Chem. Biol. Interact. 160, 1-40.

Yanez, J. A., Remsberg, C. M., Vega-Villa, K. R., Miranda, N. D., Navas, J., Ohgami, Y., McCormick, D., Hughes, K., Temple, C., Martinez, S. A. and Davies, N. M. (2008): Pharmacological evaluation of Glyco-Flex ${ }^{\circledR}$ III and its constituents on canine chondrocytes. J. Med. Sci. 8, 1-14. 